\title{
Salmonella Typhimurium, Infantis, Derby, and Enteritidis survival in pasty dulce de leche
}

\author{
Sobrevivência de Salmonella Typhimurium, Infantis, Derby e Enteritidis em doce de leite pastoso
}

Débora Rodrigues da SILVEIRA ${ }^{1}$ Nathalie Almeida LOPES ${ }^{1}$, Helenice de Lima GONZALEZ¹, Cláudio Dias TIMM ${ }^{1 \star}$

\begin{abstract}
Dulce de leche is a food obtained by concentration and heating of milk with the addition of sucrose. The common practice of opening the dulce de leche containers in retail markets can lead to food contamination by Salmonella. The objective of this study was to evaluate the survivability of Salmonella enterica subsp. enterica serotypes Typhimurium, Enteritidis, Infantis and Derby in pasty dulce de leche. Aliquots of this sweet were experimentally contaminated with these microorganisms and later analyzed to evaluate microorganism viability after storage for 0 , 1 , $2,3,5,10$, and 20 days. Salmonella was recovered up to the $20^{\text {th }}$ day. These results are a warning about the need to adopt proper sanitaryhygienic measures for handling and packaging this food aiming at food safety.

Keywords: food safety; foodborne diseases; pathogenic microorganisms.
\end{abstract}

\section{Resumo}

O doce de leite é um alimento obtido por concentração pelo aquecimento do leite com adição de sacarose. O fracionamento do produto no mercado varejista pode levar à contaminação do alimento por Salmonella. O trabalho teve como objetivo testar a capacidade de sobrevivência de Salmonella enterica subsp. enterica sorotipos Typhimurium, Infantis, Derby e Enteritidis em doce de leite pastoso. Alíquotas de doce de leite foram contaminadas experimentalmente com diferentes cepas de Salmonella e analisadas após 0, 1, 2, 3, 5, 10 e 20 dias de estocagem para verificar a viabilidade do microrganismo. Salmonella pode permanecer viável no doce de leite por 20 dias. Estes resultados são um alerta quanto à necessidade de adoção de medidas higiênico-sanitárias adequadas durante o manuseio e acondicionamento deste alimento com vistas à segurança alimentar.

Palavras-chave: segurança alimentar; doenças transmitidas por alimentos; micro-organismos patogênicos.

\section{Introduction}

Dulce de leche is a product obtained by concentration and heating of milk with the addition of sucrose (BRASIL, 1997). It is typical food of Latin America, where it is widely consumed and can be either pasty or produced in tablets. Pasty dulce de leche has low water activity and high osmolarity, which can be considered limiting for the survival of microorganisms. However, even though the product is inspected by official bodies in industries, retailers commonly open the dulce de leche packages to sell it in smaller portions according to the amount requested by the customer. The hygienic and sanitary care in handling and food processing are among the main preventive measures to avoid its contamination. Improper handling and exposure to the environment increase the risk of contamination of the product offered to the consumer, which makes it important to conduct a microbiological evaluation (TIMM et al., 2007). In their study, 28 samples of pasty dulce de leche sold in supermarkets in Pelotas city, Rio Grande do Sul, Brazil were analyzed. Salmonella and coagulase-positive Staphylococci detection was performed, and thermotolerant coliforms and mold and yeast counting was performed. The results showed that $96.4 \%$ of the samples did not meet microbiological requirements established by Brazilian legislation, and Salmonella was isolated from one sample.

Salmonella is an important pathogen that attacks the gastrointestinal tract of humans and other animals. Since it is frequently isolated from animal products, it is of great importance in food inspection to ensure food safety. An estimated 1.4 million cases of foodborne salmonellosis occur every year in the United States; approximately 40,000 are culture-confirmed by isolation (CENTERS..., 2010b). The occurrence of Salmonella in pasty dulce de leche sold in bulk was demonstrated by Timm et al. (2007). The period of time a pathogen can remain viable in food is an important factor to assess the risk that it may pose danger to consumers. The aim of this study was to test the survivability of Salmonella enterica subsp. enterica serotype Typhimurium, Infantis, Derby, and Enteritidis in pasty dulce de leche for 20 days.

\footnotetext{
Received 9/1/2012

Accepted 15/6/2012 (005561)

${ }_{1}^{1}$ Inspeção de Produtos de Origem Animal, Faculdade de Veterinária, Universidade Federal de Pelotas - UFPel, Campus Capão do Leão, Prédio 34, CEP 96010-900, Pelotas, RS, Brasil,e-mail:timm@ufpel.tche.br

${ }^{*}$ Corresponding author
} 


\section{Materials and methods}

\subsection{Strains}

Strains of Salmonella enterica subsp. enterica serotypes Typhimurium, previously isolated from pork (LIPOA 2023) and pasty dulce de leche (LIPOA 2046), Enteritidis, isolated from sausage (LIPOA 2024) and ground chicken meat (LIPOA 2030), Infantis, isolated from dry pork sausage (LIPOA 2005) and ground beef (LIPOA 2039), and Derby, isolated from ground beef (LIPOA 2035) were used.

\subsection{Dulce de leche manufacture}

The pasty dulce de leche for experimental contamination was prepared with $3 \%$ lipids-standardized milk and the addition of $200 \mathrm{~g}$ of sucrose per liter; it was kept stirring at $100-105^{\circ} \mathrm{C}$ for 2 hours and 30 minutes.

\subsection{Inoculum}

Each strain was grown in Brain Heart Infusion broth (BHI, Acumedia, Michigan, USA) at $37^{\circ} \mathrm{C}$ for 20 hours. By using serial dilutions, prepared with saline solution $0.85 \%(\mathrm{w} / \mathrm{v})$, inoculi at a concentration of approximately $10^{4}$ bacterial cells $/ \mathrm{mL}$ were prepared, so that the final concentration of $10^{2}$ bacterial cells $/ g$ can be obtained after the experimental contamination of the dulce de leche.

\subsection{Experimental contamination and verification of the viability of Salmonella}

Aliquots of $25 \mathrm{~g}$ of dulce de leche, packed in sterile plastic bags, were experimentally contaminated with $0.25 \mathrm{~mL}$ of inoculum, homogenized, and kept between 15 and $20^{\circ} \mathrm{C}$. The samples were analyzed after $0,1,2,3,5,10$ and 20 days of storage by testing the presence of Salmonella, as recommended by the U.S. Food and Drug Administration (ANDREWS; HAMMACK, 2007). Twenty-five grams of non-experimentally contaminated dulce de leche were tested to check the absence of the Salmonella and other microorganism species for negative control. The experiment was performed in triplicate.

\section{Results and discussion}

The survivability in pasty dulce de leche of four Salmonella serotypes isolated from various foods was tested, and the results showed that Salmonella can remain viable in these foods for 20 days (Table 1 ).

The ability of Salmonella to survive for long periods in foods has been reported in dairy products. Salmonella remained viable for 30 days in pasty dulce de leche in a study conducted by Hentges et al. (2010). Borges, Brandão and Pinheiro (1990), who inoculated Salmonella in raw milk prior to cheese-making and found that this enterobacteria can remain viable in this food for up to 45 days of maturation. Modi et al. (2001) also reported that this organism survives for long periods in raw milk and standardized milk. These results, as well as the ones in the current study, indicate that some strains of Salmonella are adapted to environments provided by dairy foods.

Enteritidis, isolated from ground chicken meat (LIPOA 2030), were the ones that survived the longest period of time (up to 20 days) in pasty dulce de leche. Typhimurium and Enteritidis are the most commonly isolated serotypes in the United States, and Enteritidis is one of the most common serotypes reported worldwide (CENTERS..., 2010a, b). Different strains, but of the same serotype, showed distinctive ability to survive in pasty dulce de leche, which suggests that the properties that are necessary for survival in this environment are not associated to the serotype characteristics. Likewise, there seems to be no connection between the food from which the bacterium was originally isolated and the survival time in pasty dulce de leche.

Salmonella Typhimurium strain (LIPOA 2046), used for experimental contamination, was previously isolated from pasty dulce de leche in a study conducted in the city of Pelotas, Rio Grande do Sul, by Timm et al. (2007), in which samples were analyzed in fractionated dulce de leche for retail sale in small portions. This practice increases the risk of product contamination. Considering these observations and the origin of the strain LIPOA 2046, it is likely that the microorganism, although isolated from dulce de leche, did not remain long in this food until the moment of its isolation and, therefore, it does not adapt to the environment provided by the pasty dulce de leche. These considerations would explain the relatively short survival time (3 days) of this strain in the pasty dulce de leche that was experimentally contaminated. Often, the pasty dulce de leche is consumed shortly after its purchase in the retail market, and its contamination, even by one strain that will survive for only three days in this environment, is a threat to consumers' health. Moreover, the infectious dose of Salmonella typhimurium can be less than 10 bacterial cells (D'AOUST; MAURER; BAILEY,

Table 1. Salmonella serotypes Typhimurium, Enteritidis, Infantis, and Derby in pasty dulce de leche experimentally contaminated.

\begin{tabular}{|c|c|c|c|c|c|c|c|}
\hline $\begin{array}{c}\text { Storage time } \\
\text { (days) }\end{array}$ & $\begin{array}{c}\text { Salmonella } \\
\text { Typhimurium } \\
\text { (LIPOA 2023) }\end{array}$ & $\begin{array}{c}\text { Salmonella } \\
\text { Typhimurium } \\
\text { (LIPOA 2046) }\end{array}$ & $\begin{array}{c}\text { Salmonella } \\
\text { Enteritidis } \\
\text { (LIPOA 2024) }\end{array}$ & $\begin{array}{c}\text { Salmonella } \\
\text { Enteritidis } \\
\text { (LIPOA 2030) }\end{array}$ & $\begin{array}{c}\text { Salmonella } \\
\text { Infantis } \\
\text { (LIPOA 2005) }\end{array}$ & $\begin{array}{c}\text { Salmonella } \\
\text { Infantis } \\
\text { (LIPOA 2039) }\end{array}$ & $\begin{array}{c}\text { Salmonella } \\
\text { Derdy } \\
\text { (LIPOA 2035) }\end{array}$ \\
\hline 0 & $+++^{*}$ & +++ & +++ & +++ & +++ & +++ & +++ \\
\hline 1 & +++ & +++ & +++ & +++ & +++ & +++ & +++ \\
\hline 2 & +++ & ++- & +++ & +++ & +++ & +++ & +++ \\
\hline 3 & +++ & ++- & +++ & +++ & ++- & -++ & +-- \\
\hline 5 & +++ & --- & --- & +++ & ++- & ++- & --- \\
\hline 10 & ++- & --- & --- & +++ & --- & +-- & --- \\
\hline 20 & +-- & --- & --- & +-- & --- & --- & --- \\
\hline
\end{tabular}

${ }^{\star}$ Presence (+) and absence (-) of Salmonella in $25 \mathrm{~g}$ of pasty dulce de leche in three replicates. 
2001), so that the mere presence of bacteria in food is enough to raise concerns in terms of food safety.

Salmonella Infantis strains isolated from dry pork sausage, (LIPOA 2005) and ground beef (LIPOA 2039) showed similar viability. Serotype Derby, isolated from ground beef, also had short survival time, remaining viable only until the third day in one of the repetitions. The isolation of this serotype is rarely reported in animal products, possibly due to its low survivability in foods, which may explain the relatively short survival time when compared to other serotypes studied.

\section{Conclusion}

Salmonella serotypes that are potentially pathogenic were able to survive for up to 20 days in pasty dulce de leche. Although high temperature and the time required for production of pasty dulce de leche and good manufacturing practices are enough to ensure product safety for human consumption, these results point out the need to adopt appropriate sanitary-hygienic measures for handling and packaging this food.

\section{References}

ANDREWS, W. H.; HAMMACK, T. Salmonella. In: U.S. FOOD AND DRUG ADMINISTRATION. Bacteriological analytical manual online. CFSAN, 2007. Chapter 5. Disponível em: <http://www.cfsan. fda.gov/ ebam/bam-5.html>. Acesso em: 4 ago. 2011.
BORGES, M. F.; BRANDÃO, S. C. C.; PINHEIRO, A. J. R. Sobrevivência de Salmonella spp. em queijo minas padronizado durante a maturação. Revista de Microbiologia, v. 21, n. 3, p. 276-281, 1990.

BRASIL. Ministério da Agricultura e do Abastecimento. Portaria $\mathrm{n}^{\circ} 354$, de 04 de setembro de 1997. Regulamento técnico para fixação de identidade e qualidade de doce de leite. Diário Oficial da República Federativa do Brasil, Brasília, DF, 08 set. 1997. Seção 1, p. 19685.

CENTERS OF DESEASE CONTROL AND PREVENTION - CDC. Salmonella serotype Enteritidis. National Center for Zoonotic, Vector-Borne, and Enteric Diseases, 2010a. Disponível em: <http:// www.cdc.gov/nczved/divisions/dfbmd/diseases/salmonella_ enteritidis >. Acesso em: 05 set. 2011.

CENTERS OF DESEASE CONTROL AND PREVENTION - CDC. Salmonella. CDC, 2010b. Disponível em: <http://www.cdc.gov/ salmonella/index.html>. Acesso em: 05 set. 2011.

D'AOUST, J.; MAURER, J.; BAILEY, J. S. Salmonella species. In: DOYLE, M. P.; BEUCHAT, L. R.; MONTVILlE, T. J. Food microbiology: fundamental and frontiers. 2nd ed. Washington: ASM, 2001. cap. 8, p. 141-77.

HENTGES, D. et al. Pathogenic microorganism survival in dulce de leche. Food Control, v. 21, n. 9, p. 1291-1293, 2010. http://dx.doi. org/10.1016/j.foodcont.2010.02.014

MODI, R. et al. Effect of phage on survival of Salmonella Enteritidis during manufacture and storage of cheddar cheese made from raw and pasteurized milk. Journal of Food Protection, v. 64, n. 7, p. 927-933, 2001.

TIMM, C. D. et al. Avaliação microbiológica de doce de leite pastoso. Revista Instituto Adolfo Lutz, v. 66, n. 3, p. 275-277, 2007. 